\title{
Kedudukan hukum dan hak waris anak hasil inseminasi buatan dari ayah yang telah meninggal
}

\author{
Cindy Olivia Susanto ${ }^{1}$, Siti Hamidah ${ }^{2}$, Rachmi Sulistyarini ${ }^{3}$
}

${ }^{1}$ Cindy Olivia Susanto; Fakultas Hukum Universitas Brawijaya; Jalan MT. Haryono No. 169; Malang; 65145; Jawa Timur; Indonesia.

${ }^{2}$ Siti Hamidah; Fakultas Hukum Universitas Brawijaya; Jalan MT. Haryono No. 169; Malang; 65145; Jawa Timur; Indonesia.

${ }^{3}$ Rachmi Sulistyarini; Fakultas Hukum Universitas Brawijaya; Jalan MT. Haryono No. 169; Malang; 65145; Jawa Timur; Indonesia.

\section{ARTICLEINFO}

\section{Article history:}

Received 2020-09-01

Received in revised form

2020-11-15

Accepted 2020-12-01

Kata kunci:

Waris; Inseminasi Buatan;

Kedudukan Hukum.

Keywords:

Inheritance; Artificial insemination; Legal Position.

DOI: https://doi.org/10.26905/ idjch. v11i3. 5475.

\section{How to cite item:}

Susanto, C., Siti Hamidah, S., \& Rachmi Sulistyarini, R. (2020). Kedudukan hukum dan hak waris anak hasil inseminasi buatan dari ayah yang telah meninggal. Jurnal Cakrawala Hukum, 11(3). 302-312. doi:10.26905/idjch.v11i3.5475.

\section{Corresponding Author:}

* Cindy Olivia Susanto.

E-mail address:cindyoliviasusanto@gmail.com

\section{Abstrak}

Penelitian ini bertujuan untuk menganalisis Kedudukan Hukum Anak Hasil Inseminasi Buatan Dari Ayah Yang Telah Meninggal Ditinjau Dalam Perspektif Hukum Positif Indonesia serta untuk menemukan Hak Waris Untuk Anak Hasil Inseminasi Buatan Dari Ayah Yang Telah Meninggal Ditinjau Dalam Perspektif Hukum Positif Indonesia. Putusan pengadilan akan mempengaruhi apakah inseminasi buatan dari sel sperma suami yang telah meninggal dapat dilakukan atau tidak. Putusan pengadilan yang memberikan putusan untuk dapat dilakukan akan mempengaruhi kedudukan hukum anak hasil inseminasi buatan dari ayah yang telah meninggal. Bila anak tersebut lahir hidup maka kedudukan hukum anak hasil inseminasi buatan dari ayah yang telah meninggal menurut Kitab UndangUndang Hukum Perdata adalah anak sah sesuai dengan Pasal 250 KUHPerdata, menurut Hukum Islam kedudukan hukum anak hasil inseminasi buatan dari ayah yang telah meninggal merupakan anak sah, serta menurut hukum adat bahwa anak tersebut merupakan anak sah hal ini dipersamakan dengan mengangkat anak dalam masyarakat adat. Hak waris anak hasil inseminasi buatan dari ayah yang telah meninggal mempunyai hak mewaris.

\section{Abstract}

This research aims to analyze Artificial Insemination Children's Standing and discover Their Hereditary Right from a Deceased Father viewed in Indonesia's Positive Law. Judgment will affect to whether artificial insemination from the deceased husband's sperm can be performed or not. Further, the judgment that decide the artificial insemination can be performed will affect children's standing from a deceased father. If the children are born alive, then the standing is legal based on 


\section{Kedudukan hukum dan hak waris anak hasil inseminasi buatan dari ayah yang telah meninggal}

Cindy Olivia Susanto, Siti Hamidah, Rachmi Sulistyarini.

Article 250 of Civil Code, Islamic Law (Sharia law), and customary law. In addition, customary law claims the standing as adopt them on culture. Artificial insemination children's hereditary right from a deceased father has the right to inherit (as heir).

\section{Pendahuluan}

Perkembangan teknologi modern dalam bidang kesehatan berguna untuk membantu dan memberikan manfaat dalam peningkatan kualitas kehidupan di dalam masyarakat. Dapat dikatakan bahwa permasalahan tentang kesehatan dapat mempengaruhi segala segi kehidupan manusia, bukan saja mempengaruhi kehidupan manusia pada saat ini akan tetapi akan mempengaruhi kehidupan manusia di masa yang akan datang, sehingga perkembangan pemikiran dalam bidang kesehatan akan selalu berubah mengikuti perkembangan ilmu dan teknologi.

Perkembangan ilmu dan teknologi dalam bidang kesehatan di Negara Indonesia tentunya diatur oleh Hukum yang berlaku. Misalnya aturan tentang kesehatan di Negara Indonesia diatur di dalam Undang-undang Nomor 36 Tahun 2009 Tentang Kesehatan yang menjelaskan bahwa kesehatan merupakan keadaan sehat, baik secara fisik, mental, spiritual ataupun sosial yang dapat memungkinkan setiap orang untuk hidup produktif secara sosial dan ekonomis. Konsep aturan ini sejalan dengan perkembangan ilmu dan teknologi yang telah mempengaruhi pemikiran masyarakat untuk meningkatkan kehidupannya dengan melanjutkan keturunan.

Manusia yang berada dalam suatu negara pastinya tidak bisa terlepas dari masyarakat yang lain, dimana dalam melangsungkan kehidupannya memiliki hak untuk mendapatkan kemerdekaan, hak untuk hidup, hak untuk memiliki dan hak untuk mengeluarkan pendapat, karena manusia merupakan suatu makhluk sosial. Makhluk sosial ini tidak dapat dipisahkan dari lingkungan masya- rakat karena manusia sejak lahir sampai dengan meninggal berkembang dalam lingkungan masyarakat, dapat dikatakan bahwa dalam hal ini manusia sosial hidup berdampingan dengan masyarakat yang lain. Dengan hidup berdampingan tersebut, maka antara manusia satu dengan manusia yang lain, serta antara pria dan wanita berusaha untuk meneruskan keturunan dengan cara melangsungkan perkawinan.

Perkawinan merupakan salah satu hal yang dapat diterima dalam siklus kehidupan manusia. Karena munculnya siklus kehidupan manusia itu sendiri dimulai dari adanya suatu perkawinan. Dengan adanya perkawinan, maka akan timbul hubungan hukum antara suami dan istri yang berisi hak dan kewajiban. Salah satu Hak dan kewajiban yang timbul dari adanya perkawinan adalah hak dan kewajiban untuk saling memenuhi kebutuhan biologis antara suami dan istri, yang dimana pemenuhan biologis tersebut guna melanjutkan keturunan.

Perkawinan merupakan sebuah pertalian yang sah antara seorang lelaki dan seorang perempuan untuk waktu yang lama (Subekti, 2003). Adapun tujuan lain dilakukannya perkawinan untuk memperoleh keturunan (anak). Di dalam kepercayaan orang Indonesia, perkawinan yang tidak mempunyai keturunan adalah suatu perkawinan yang tidak berhasil (Afandi, 1986).

Anak memiliki arti yang sangat penting dalam suatu perkawinan. Karena dengan adanya anak, maka terdapat penerus keturunan dan sebagai ahli waris dari orang tuanya. Dengan adanya anak di dalam perkawinan ataupun keluarga dapat membantu mempererat hubungan antara pasangan 


\section{Jurnal Cakrawala Hukum, Volume 11 No. 3 Desember 2020}

ISSN PRINT 2356-4962 ISSN ONLINE 2598-6538

untuk memiliki rasa saling menyayangi yang lebih antara pasangan tersebut.

Permasalahan yang sering terjadi di dalam perkawinan adalah ketika dalam perkawinan tersebut dinyatakan tidak dapat memiliki keturunan karena terdapat masalah di dalam tubuh salah satu pasangan. Permasalahan yang sering terjadi tersebut menimbulkan pemikiran dari pasangan suami istri untuk melakukan inseminasi buatan, yang dimana inseminasi buatan ialah salah satu upaya pembuahan melalui rahim hewan ataupun manusia untuk mendapatkan keturunan tanpa melalui proses kopulasi alamiah.

Di dalam Pelaksanaannya, banyak pasangan yang akan melakukan IVF (misalnya sudah memulai proses perawatan IVF), di tengah kebahagiaan pasangan yang akan menanti keturunan mereka terdapat resiko yang setiap manusia tidak dapat menduganya, yaitu kematian. Karna kematian seseorang tidak pernah kita ketahui kapan akan datang.

Seperti kasus yang terjadi di New South Wales Australia, pasangan suami istri Markus Edwards dan Jocelyn Edwards berencana melakukan program bayi tabung. Keduanya secara resmi telah memulai proses perawatan IVF atau bayi tabung di sebuah klinik kesuburan pada tahun 2010. Tapi suatu hari sebelum pasangan tersebut melakukan penandatanganan resmi untuk program bayi tabung, sang suami Markus Edwards meninggal dalam kecelakaan di tempat kerja pada Agustus 2010. Markus yang bekerja sebagai installer televisi kabel jatuh dari balkon di tempat kerja.

24 jam setelah kematian suaminya, Jocelyn berhasil meyakinkan hakim untuk mengeluarkan putusan untuk mengambil sperma dari tubuh suaminya yang telah meninggal dunia dan disimpan di laboratorium. Pertimbangan dari hakim untuk mengambil sperma dari tubuh suami Jocelyn yang telah meninggal dunia untuk memberikan ketenangan kepada Jocelyn sebagai pemilik harta terakhir (anak) dari suaminya yang telah meninggal dunia, walaupun Hakim Hulme tidak memiliki bukti langsung tetapi Hakim Hulme menyimpulkan dengan jelas bahwa Jocelyn dan Markus berkeinginan untuk memiliki anak dengan bantuan perawatan reproduksi IVF atau bayi tabung. Di dalam kasus ini Jocelyn juga memberikan penjelasan bahwa ini keputusan yang tepat untuk dirinya, Mark akan sangat bahagia disana, kami akan mempunyai bayi kami sendiri, itu yang kami rencanakan, saya (Jocelyn) hanya ini mendapatkan hari terakhir dan menikmatinya.

Dengan adanya kasus ini, maka akan muncul pemikiran seseorang akan berjuang untuk memiliki keturunan yang diinginkan oleh pasangan suami istri walaupun suami telah meninggal dunia, dimana anak yang akan dilahirkan merupakan suatu harta terakhir yang akan menjadi kebahagiaan dari pihak yang telah ditinggalkan (meninggal dunia) seperti munculnya pemikiran dilakukannya bayi tabung untuk membantu pasangan yang infertil (tidak subur) di seluruh dunia untuk dapat memiliki keturunan dari rahim istri sendiri dan menghilangkan rasa kekecewaan dan trauma psikologis yang dapat muncul karna ada tekanan dari luar bila pasangan tersebut tidak memiliki keturunan.

Berdasarkan uraian diatas, maka penulis ingin mengangkat bagaimana Kedudukan Hukum Dan Hak Waris Anak Hasil Inseminasi Buatan Dari Ayah Yang Telah Meninggal (Ditinjau Dalam Perspektif Hukum Positif Indonesia). Penulis tertarik untuk mengangkat permasalahan ini dan melihat dari perspektif Hukum Positif Indonesia karena menurut Hukum Positif Indonesia Pewarisan terbuka saat adanya kematian. Sedangkan di dalam kasus ini, Ahli Waris lahir setelah pewaris meninggal.

Ahli waris baru akan ada setelah pewaris meninggal inilah yang nantinya akan berkaitan dengan pembagian pewarisan yang diterima oleh ahli waris tersebut, dimana Pembagian pewarisan sudah dilakukan sedangkan ahli waris tersebut 


\section{Kedudukan hukum dan hak waris anak hasil inseminasi buatan dari ayah yang telah meninggal \\ Cindy Olivia Susanto, Siti Hamidah, Rachmi Sulistyarini.}

baru lahir. Untuk itu peneliti ingin melihat bagaimana Kedudukan Hukum Dan Hak Waris Anak Hasil Inseminasi Buatan Dari Ayah Yang Telah Meninggal menurut Perspektif Hukum Positif Indonesia. Apabila permasalahan ini sampai terjadi di Indonesia, maka harus ada pengaturan terkait kedudukan hukum anak tersebut dan hak untuk mewarisnya, karna kita tidak pernah mengetahui kapan kasus ini akan terjadi di Indonesia, seperti kasus Inseminasi Buatan yang sekarang juga berkembang di Indonesia.

\section{Metode}

Jenis penelitian yang digunakan penulis dalam penelitian ini adalah jenis penelitian yuridisnormatif. Pendekatan penelitian dalam penelitian ini adalah pendekatan perundang-undangan dan pendekatan konsep. Metode penelitian yuridisnormatif adalah suatu penelitian yang objeknya merupakan dokumen peraturan perundangundangan dan bahan pustaka (Abdurahman, 2003). Dalam penelitian ini peneliti menganalisis dan untuk menemukan Kedudukan Hukum Dan Hak Waris Anak Hasil Inseminasi Buatan Dari Ayah Yang Telah Meninggal Ditinjau Dalam Perspektif Hukum Positif Indonesia.

\section{Pembahasan}

Keturunan dapat diperoleh apabila sepasang pria dan wanita melangsungkan perkawinan. Dengan adanya perkawinan maka akan timbul hak dan kewajiban bagi para pihak. Hak dan kewajiban yang tersebut ialah untuk saling memenuhi kebutuhan biologis untuk melanjutkan keturunan.

Memperoleh keturunan merupakan hal terpenting dalam sebuah perkawinan. Akan tetapi terdapat permasalahan yang sering terjadi dalam sebuah perkawinan apabila terdapat masalah di dalam salah satu pasangan yang dapat menghambat memperoleh keturunan. Dengan perkembangan zaman sekarang ini maka teknologi juga ikut berkembang salah satunya teknologi dalam bidang kesehatan. Teknologi di dalam bidang kesehatan ialah In Vitro Fertilization atau yang biasa dikenal dengan bayi tabung. Akan tetapi setiap manusia tidak dapat mengetahui siklus kehidupan manusia yaitu kematian akan datang.

Seperti kasus yang terjadi di New South Wales Australia, pasangan suami istri Markus Edwards dan Jocelyn Edwards berencana melakukan program bayi tabung. Keduanya secara resmi telah memulai proses perawatan IVF atau bayi tabung di sebuah klinik kesuburan pada tahun 2010. Tapi suatu hari sebelum pasangan tersebut melakukan penandatanganan resmi untuk program bayi tabung, sang suami Markus Edwards meninggal dalam kecelakaan di tempat kerja pada Agustus 2010. Markus yang bekerja sebagai installer televisi kabel jatuh dari balkon di tempat kerja.

24 jam setelah kematian suaminya, Jocelyn berhasil meyakinkan hakim untuk mengeluarkan putusan untuk mengambil sperma dari tubuh suaminya yang telah meninggal dunia dan disimpan di laboratorium. Dengan adanya kasus ini, maka akan muncul pemikiran seseorang akan berjuang untuk memiliki keturunan yang diinginkan oleh pasangan suami istri walaupun suami telah meninggal dunia, dimana anak yang akan dilahirkan merupakan suatu harta terakhir yang akan menjadi kebahagiaan dari pihak yang telah ditinggalkan (meninggal dunia) seperti munculnya pemikiran dilakukannya bayi tabung untuk membantu pasangan yang infertil (tidak subur) di seluruh dunia untuk dapat memiiliki keturunan dari rahim istri sendiri dan menghilangkan rasa kekecewaan dan trauma psikologis yang dapat muncul karna ada tekanan dari luar bila pasangan tersebut tidak memiliki keturunan.

Terdapat beberapa pengaturan terkait Inseminasi Buatan bagi pasangan suami istri yang masih hidup, akan tetapi tidak berlaku bagi Inseminasi Buatan dari sel sperma suami yang telah meninggal apabila tidak adanya putusan pengadilan, maka 
kita harus mengetahui apakah Inseminasi Buatan dari sel sperma suami yang sudah meninggal dapat dilakukan. Berbagai kasus yang ada terkait Inseminasi Buatan dari sel sperma ayah yang telah meninggal dapat dilakukan apabila Hakim Pengadilan dapat memberikan Putusan apakah sel sperma suami yang telah meninggal dapat diambil atau tidak. Beberapa kasus yang ada Hakim memberikan putusan untuk mengijinkan pengambilan sel sperma suami yang telah meninggal dengan alasan bahwa istri dari suami tersebut memiliki hak untuk mendapatkan sel sperma tersebut karna sebagai harta terakhir yang diberikan oleh suaminya. Bahwa di dalam hal ini sel sperma dapat disamakan dengan Harta terakhir, dimana Harta tersebut dapat dimiliki oleh Ahli Warisnya yaitu istrinya.

Di dalam kasus ini Putusan pengadilan memiliki peranan penting agar Inseminasi Buatan dari sel sperma ayah yang telah meninggal dapat dilakukan, karna kasus inseminasi buatan dari sel sperma suami yang telah meninggal belum diatur di dalam Undang-undang. Dengan adanya putusan pengadilan dapat menyelesaikan atau mengakhiri suatu permasalahan guna terciptanya kepastian hukum, kemanfaatan dan keadilan bagi pihak yang memperjuangkan haknya. Sifat putusan pengadilan bersifat tetap dan sementara.

Putusan pengadilan Tetap berarti para pihak telah menerima putusan dari hakim dan tidak ada upaya hukum. Asas dalam Putusan pengadilan harus memuat alasan hukum, harus dilakukan di dalam sidang terbuka untuk umum, dibuat tersendiri dan memuat pertimbangan hakim. Pertimbangan hakim ini sesuai dengan Pasal 16 (1) UU No 4 tahun 2004 yang menyatakan bahwa "hakim sebagai organ pengadilan dianggap memahami hukum pencari keadilan, andaikata ia tidak menemukan hukum tertulis, ia wajib menggali hukum tidak tertulis untuk memutuskan berdasarkan hukum sebagai seorang yang bijaksana dan bertanggung jawab penuh kepada Tuhan YME, diri sendiri, masyarakat, bangsa, dan negara."

Terdapat istilah Ius Curia Novit: hakim dianggap tahu akan hukum. Apabila tidak ada hukumnya, hakim harus melakukan penemuan hukum. Hakim ada untuk membantu memecahkan suatu masalah. Dan Kekuatan putusan hakim di dalam pengadilan mengikat para pihak baik ahli waris ataupun orang yang mendapatkan haknya, kekuatan bukti dalam putusan pengadilan merupakan akta otentik dan hanya putusan pengadilan yang dapat dilaksanakan. Dengan adanya putusan pengadilan dapat menentukan inseminasi buatan dengan sel sperma suami yang telah meninggal dapat dilakukan dan hal ini nantinya akan menentukan kedudukan hukum dan hak waris anak yang akan lahir dari inseminasi buatan dari ayah yang telah meninggal.

\section{Kedudukan hukum anak hasil inseminasi buatan dari ayah yang telah meninggal ditinjau dalam perspektif hukum positif Indonesia}

Berbagai kasus yang ada terkait Inseminasi Buatan terjadi di Indonesia bagi pasangan suami istri yang masih hidup, akan tetapi terdapat beberapa hal tidak berlaku bagi Inseminasi Buatan dari sel sperma suami yang telah meninggal apabila tidak adanya putusan pengadilan, maka kita harus mengetahui apakah Inseminasi Buatan dari sel sperma suami yang sudah meninggal dapat dilakukan Inseminasi Buatan dari sel sperma ayah yang telah meninggal dapat dilakukan apabila Hakim Pengadilan dapat memberikan Putusan apakah sel sperma suami yang telah meninggal dapat diambil atau tidak.

Beberapa kasus yang ada Hakim memberikan putusan untuk mengijinkan pengambilan sel sperma suami yang telah meninggal dengan alasan 


\section{Kedudukan hukum dan hak waris anak hasil inseminasi buatan dari ayah yang telah meninggal \\ Cindy Olivia Susanto, Siti Hamidah, Rachmi Sulistyarini.}

bahwa istri dari suami tersebut memiliki hak untuk mendapatkan sel sperma tersebut karna sebagai harta terakhir yang diberikan oleh suaminya. Bahwa di dalam hal ini sel sperma dapat disamakan dengan Harta terakhir, dimana Harta tersebut dapat dimiliki oleh Ahli Warisnya yaitu istrinya.

\section{a. Menurut perspektif kitab undang- undang Hukum Perdata}

Bila dilihat melalui penjelasan Pada Pasal 127 Undang-undang Nomor 36 Tahun 2009 Tentang kesehatan dengan Kitab Undang-undang Hukum Perdata maka dapat dikaitkan bila inseminasi buatan dari ayah yang telah meninggal dapat dilakukan karna hal itu merupakan sel sperma dengan ovum dari suami istri yang bersangkutan, walaupun istri masih hidup dan suami telah meninggal. Kedudukan hukum anak hasil inseminais buatan dari ayah yang telah meninggal bila ditinjau dalam perspektif Kitab Undangundang Hukum Perdata maka anak tersebut dapat digolongkan sebagai anak sah.

Ada beberapa pendapat yang dapat memperkuat argumen penulis

1) Bismar Siregar, mengemukakan bahwa: "Lahirnya keturunan melalui bayi inseminasi buatan, bukan sesuatu yang haram, tetapi kebolehan, dengan syarat dan ketentuan benih dari suami, lahannya rahim istri. Kedudukan anaknya sah. Sedangkan di luar itu haram tergolong perzinahan, jangan memasyarakatkan (Siregar, 1989)."

2) Sudikno Mertokusumo mengemukakan bahwa "Dengan lahirnya teknologi yang canggih yang mengahasilkan bayi inseminasi buatan, sepasang suami istri yang tidak mempunyai anak dan menginginkannya makin lama akan makin lebih suka memperoleh bayi tabung daripada mengangkat anak orang lain (hal ini tergantung pada pendidikan dan kesadaran). Kedudukan Yuridis bayi inseminasi buatan pun sama halnya anak angkat, yaitu "menggantikan" atau sama dengan anak kandung. Jadi anak yang dilahirkan melalui inseminasi buatan hak dan kewajibannya sama dengan anak kandung. Ia berhak atas pemeliharaan, pendidikan dan arisan dari orang tuanya (Siregar, 1989)."

3) Purwoto $S$ Gandasubrata, menyatakan bahwa: "Hukum di Indonesia sebenarnya telah memberikan jalan kepada sepasang suami istri yang tidak dikarunai anak atau keturunan untuk menggunakan lembaga hukum; mengangkat anak atau adopsi, anak piara, anak pungut, anak asuh dan sebagainya untuk mengisi kekosongan dalam hidup kekeluargaan/rumah tangganya. Selain itu dapat pula ditempuh cara lain yang dirasakan kurang terpuji, yakni; berpoligami secara baik dengan persetujuan istri yang mandul apabila hukumnya membenarkan itu ataupun dengan melakukan "kawin kontrak" khusus untuk memperoleh anak yang kurang manusiawi. Namun apabila jalan hukum itu tidak ingin ditempuh, maka proses "bayi inseminasi buatan" yang menggunakan ovum berasal dari pasangan suami istri dan embrionya dipindahkan ke dalam rahim istri itulah yang masih dapat diterima atau dipertanggungjawabkan sebagai "pintu darurat" yang menurut hukum dan mungkin menurut agama masih dapat dibenarkan" (Gandasubrata, 1989).

Pada prinsipnya bila dilihat dari pendapatpendapat diatas bahwa para ahli juga menyetujui penggunaan teknik inseminasi buatan yang menggunakan sperma dan ovum dari pasangan suami istri yang sah yang mana embrionya ditransplantasikan ke dalam rahim istri dan kedudukan hukum anak tersebut adalah sebagai anak sah, bila Ia lahir hidup sehingga hak dan kewajibannya sama dengan anak yang dilahirkan melalui proses alamiah. 


\section{Jurnal Cakrawala Hukum, Volume 11 No. 3 Desember 2020}

ISSN PRINT 2356-4962 ISSN ONLINE 2598-6538

Di dalam permasalahan ini bila dilihat dari perspektif Kitab Undang-undang Hukum Perdata, Jika anak tersebut lahir hidup maka kedudukan hukum anak tersebut merupakan anak sah. Apabila anak tersebut meninggal saat di dalam kandungan ataupun saat dilahirkan maka anak tersebut tidak memiliki kedudukan hukum. Anak yang dilahirkan dalam keadaan hidup dapat dikatakan sebagai anak sah karena, suami yang telah meninggal dapat dikatakan bahwa suami tersebut merupakan pasangan yang sah dari istrinya. Apabila melakukan inseminasi buatan maka hal tersebut dapat dibenarkan karna suami yang telah meninggal dengan istri yang masih hidup pada dasarnya merupakan pasangan suami istri yang sah. Hal ini sesuai dengan Pasal 250 Kitab Undang-undang Hukum Perdata yang menyatakan bahwa:

"tiap-tiap anak yang dilahirkan atau ditumbuhkan sepanjang perkawinan, memperoleh si suami sebagai bapaknya."

Menurut penulis bahwa anak hasil inseminasi buatan dari ayah yang telah meninggal dapat dikatakan sebagai anak sah, karna perkawinan antara suami dan istri tersebut sudah dilangsung terlebih dahulu, Walaupun anak tersebut lahir setelah ada putusnya perkawinan yaitu kematian. Akan tetapi perkawinan sudah dilangsungkan dan anak tersebut lahir dari benih ibu yang masih hidup dan benih ayah yang telah meninggal setelah adanya perkawinan, bukan sebelum adanya perkawinan. Bila sebelum adanya perkawinan maka anak tersebut dapat dikatakan kedudukannya sebagai anak luar kawin.

\section{b. Menurut perspektif Hukum Islam}

Menurut Pandangan Hukum Islam dan Fatwa MUI yang telah dijabarkan diatas dapat dikaitkan dengan permasalahan Anak hasil inseminasi buatan dari ayah yang telah meninggal bergantung dari sah atau tidaknya perkawinan orang tua yang melahirkannya, yaitu pada saat terjadinya pembuahan. Pembuahan tersebut terjadi sesudah dilaksanakan perkawinan atau ijab kabul atau pembuahan tersebut terjadi sebelum adanya perkawinan. Apabila pembuahan tersebut terjadi sesudah adanya perkawinan maka anak tersebut dapat dikatakan sebagai anak sah, dan bila pembuahan tersebut terjadi sebelum adanya perkawinan maka anak tersebut bukan anak sah dari pasangan suami istri tersebut. Hal ini sesuai dengan kaidah hukum Fiqih Islam yang menyatakan "Hajat (kebutuhan yang sangat penting itu) diperlukan seperti dalam keadaan terpaksa. Padahal keadaan darurat/ terpaksa itu membolehkan melakukan hal-hal terlarang."

Karna kasus ini dilakukan dengan pengambilan sel sperma suami yang telah meninggal dan disimpan dalam laboratorium atau yang dapat disebut dengan "sperma freezing" maka kasus ini dapat disamakan juga dengan menurut pendapat ulama yang menyatakan bahwa "penyimpanan sel sperma yang dibekukan boleh dilakukan sebelum selesai waktu "iddah istri" hal tersebut diperbolehkan dengan syarat : 1) Terdapat indikasi bahwa mandul dan bisa jadi menghasilkan anak yang cacat karna penyakit tertentu. Hal ini dapat dikategorikan sebagai berobat dan merupakan jalan satu-satunya yang dapat dilakukan, karna di dalam hal ini pembekuan sperma sesuai dengan syariat; 2) Penyimpanan sel sperma yang dibekukan dilakukan secara profesional dan benar-benar terjaga dari tercampur atau tertukar dengan orang lain; 3) Fatwa boleh ini bukan fatwa yang diberlakukan secara umum, akan tetapi fatwa untuk individu karena setiap orang berbeda permasalahannya.

\section{c. Menurut perspektif Hukum Adat}

Dapat dikatakan bahwa hukum adat dapat menerima inseminasi buatan dilakukan dengan sel sperma suami yang telah meninggal apabila Hakim memberikan putusan untuk memperbolehkan 


\section{Kedudukan hukum dan hak waris anak hasil inseminasi buatan dari ayah yang telah meninggal \\ Cindy Olivia Susanto, Siti Hamidah, Rachmi Sulistyarini.}

dilakukan. Karna hukum adat akan selalu mengikuti perubahan yang terus menerus melalui keputusan yang dikeluarkan untuk kepentingan masyarakat, sebagaimana sifat komunal masyarakat hukum adat. Di dalam permasalahan ini bila dilihat dari perspektif Hukum Adat, Jika anak hasil inseminasi buatan dari ayah yang telah meninggal tersebut lahir hidup maka kedudukan hukum anak tersebut merupakan anak sah.

Dalam hal ini penulis mempersamakan kedudukan hukum anak hasil inseminasi buatan dari ayah yang telah meninggal dengan anak yang dilahirkan setelah perceraian. Penulis mempersamakan kedua hal tersebut karna anak tersebut lahir setelah putusnya perkawinan dari ibu dan ayah. Perceraian dalam hal ini dapat dianggap sebagai meninggal. Menurut hukum adat anak yang dilahirkan setelah perceraian maka tetap memiliki bapak (bekas suami ibu yang melahirkannya).

Selain itu, penulis menganalisis kedudukan hukum anak hasil inseminasi buatan dari ayah yang telah meninggal dari segi hukum adat yang memperbolehkan untuk mengangkat anak agar keluarga tersebut memiliki keturunan untuk dapat melanjutkan generasinya terus menerus. Daripada istri tersebut mengangkat anak untuk dapat melanjutkan keturunannya secara terus menerus, lebih baik menggunakan sel sperma suaminya yang telah meninggal untuk dapat memiliki keturunan yang sesuai dengan silsilah keluarganya.

Hukum adat membedakan pengaturan sistem kekerabatannya dalam mengatur pemeliharaan anak yatim piatu. Bila salah satu orang tuanya telah meninggal dan ada anak yang baru lahir tersebut, maka anak tersebut dipelihara dalam susunan keturunan pihak suami atau istri yang masih hidup. Dalam keluarga matrilineal, jika yang meninggal suami maka istri yang mengambil alih kuasa, jika istri yang meninggal, maka anak dipelihara terus oleh kerabat ibunya. Dalam keluarga patrilineal, jika suami meninggal, maka anak-anak dipelihara oleh istri dan bila istri meninggalkan rumah, maka anak tetap pada kekuasaan almarhum suami.

\section{Hak waris anak hasil inseminasi buatan dari ayah yang telah meninggal ditinjau dalam perspektif hukum positif Indonesia}

Penulis menganalisis hak waris ini agar anak hasil inseminasi buatan dari ayah yang telah meninggal dapat dilindungi hak waris nya dan anak tersebut memiliki hak yang sesuai dengan aturan yang telah ditentukan agar hak waris dari ayah yang telah meninggal memberikan kebahagiaan bagi ahli waris serta pembagian hak waris tersebut harus sesuai dengan konsep keadilan agar tidak merugikan ahli waris yang lain serta anak tersebut.

\section{a. Menurut perspektif kitab undang-undang Hukum Perdata}

Sebelumnya telah ditentukan bahwa kedudukan anak yang dilahirkan melalui proses inseminasi buatan yang menggunakan sperma suami adalah anak sah. Oleh karena itu dilahirkan dalam atau sebagai akibat perkawinan yang sah, walaupun proses pembuahannya di luar upaya alamiah. Dan anak jenis ini dapat disamakan dengan anak kandung. Anak kandung berhak untuk mendapatkan warisan orang tua kandungnya, apabila orang tuanya (pewaris) telah meninggal dunia (Pasal 830 BW).

Sistem waris dalam Hukum Perdata, terhadap kedudukan anak dikenal dengan bagian mutlak atau legitieme portie yang diatur dalam pasal 913 KUHPerdata: Bagian mutlak atau legitieme portie, adalah bagian dari harta peninggalan yang diberikan kepada para waris dalam garis lurus menurut undang-undang terhadap bagian si meninggal tidak diperbolehkan menetapkan sesuatu, baik selaku pemberian antara yang masih hidup maupun selaku wasiat. 


\section{Jurnal Cakrawala Hukum, Volume 11 No. 3 Desember 2020}

ISSN PRINT 2356-4962 ISSN ONLINE 2598-6538

Akan tetapi yang dijadikan permasalahan bahwa anak hasil inseminasi buatan dari ayah yang telah meninggal lahir ketika pewaris telah meninggal. Anak tersebut mempunyai kedudukan hukum sebagai anak sah dari ayah dan ibunya karna dilahirikan setelah adanya perkawinan. Anak tersebut memiliki hak untuk mewaris, akan tetapi anak tersebut menurut penulis tidak memiliki hak waris dari ayahnya. Dikarenakan adanya asas yang mengatur tentang pewarisan menurut Pasal 836 Kitab Undang-undang Hukum Perdata bahwa:

"agar dapat bertindak sebagai waris, seorang harus telah ada, pada saat warisan jatuh meluang."

Sedangkan anak atau ahli waris tersebut baru lahir setelah pewaris meninggal.

Anak hasil inseminasi buatan dari ayah yang telah meninggal menurut penulis hanya dapat menerima hak waris dari Ibunya saja apabila ibunya meninggal dikemudian hari, karna anak hasil inseminasi buatan dari ayah yang telah meninggal lahir dalam keadaan ibu yang masih hidup (dengan sel telur ibu yang masih hidup) dan ayah yang telah meninggal (dengan sel sperma aya yang telah meninggal) Dan Anak hasil inseminasi buatan dari ayah yang telah meninggal akan mendapatkan bagian (Afandi, 1986): 1) Kalau hanya ada seorang anak sah, mkaa bagiannya $1 / 2$ dari bagian itu jika ia mewaris tanpa testamen; 2) Kalau terdapat 2 orang anak maka bagiannya 2/3 tanpa testamen; 3 ) Kalau terdapat 3 orang anak atau lebih maka bagiannya $3 / 4$ bagian tanpa testamen; 4 J Jika tidak ada anak, maka kedudukannya diganti oleh anakanaknya dan begitu seterusnya.

\section{b. Menurut perspektif Hukum Islam}

Kedudukan hukum anak hasil inseminasi buatan dari ayah yang telah meninggal merupakan anak sah, maka anak tersebut dapat memiliki hak untuk mewaris dari orang tuanya. Yang menjadi permasalahan adalah ketika pewarisan tersebut dilaksanakan oleh pewaris, anak tersebut belum ada atau belum lahir. Karna menurut Hukum Islam sendiri, Syarat Pewarisan dapat terjadi bila "Ahli waris yang masih hidup setelah meninggalnya pewaris atau karena keputusan hakim bahwa orang tersebut berdasarkan keyakinan dan setelah ditinjau masih dalam keadaan hidup."

Jadi dapat disimpulkan bahwa anak hasil inseminasi buatan dari ayah yang telah meninggal dapat mewaris dari garis Ibu saja, karna pewarisan tersebut akan terjadi ketika Ibunya meninggal dikemudian hari, karna anak hasil inseminasi buatan dari ayah yang telah meninggal lahir dalam keadaan ibu yang masih hidup (dengan sel telur ibu yang masih hidup) dan ayah yang telah meninggal (dengan sel sperma aya yang telah meninggal). Dan Anak hasil inseminasi buatan dari ayah yang telah meninggal akan mendapatkan bagian:

1) $1 / 2$ Bagian

Seorang anak perempuan, bila tidak menjadi ashobal bil ghoiri (adanya anak laki-laki)

2) $2 / 3$ Bagian

Dua atau lebih anak perempuan, dibagi bersama-sama

3) Ashobah Binafsihi

a) Jika anak lelaki tunggal, maka menerima bagian ashobah seluruhnya

b) Jika anak lelaki lebih dari 1, seluruh bagian ashobah dibagi rata diantara mereka

c) Jika bersama anak perempuan, maka dibagi dengan perbandingan 2:1

4) Ashobah Bilghoiri

Jika Anak perempuan beserta anak laki-laki

\section{c. Menurut perspektif Hukum Adat}

Telah ditentukan bahwa kedudukan anak yang dilahirkan melalui proses inseminasi buatan yang menggunakan sperma suami adalah anak sah. Karna Dalam hal ini penulis mempersamakan 


\section{Kedudukan hukum dan hak waris anak hasil inseminasi buatan dari ayah yang telah meninggal \\ Cindy Olivia Susanto, Siti Hamidah, Rachmi Sulistyarini.}

kedudukan hukum anak hasil inseminasi buatan dari ayah yang telah meninggal dengan anak yang dilahirkan setelah perceraian. Penulis mempersamakan kedua hal tersebut karna anak tersebut lahir setelah putusnya perkawinan dari ibu dan ayah. Perceraian dalam hal ini dapat dianggap sebagai meninggal. Menurut hukum adat anak yang dilahirkan setelah perceraian maka tetap memiliki bapak (bekas suami ibu yang melahirkannya). Oleh karena itu anak hasil inseminasi buatan dari ayah yang telah meninggal memiliki hak untuk mewaris dalam hukum adat.

Anak hasil inseminasi buatan dari ayah yang telah meninggal dapat memiliki hak waris bila dilihat dari bentuk kekerabatannya. Bila anak hasil inseminasi buatan dari ayah yang telah meninggal dilihat dari bentuk kekerabatannya maka:

a) Masyarakat matrilineal

Bila anak yang lahir perempuan maka anak tersebut dapat memiliki hak waris dari garis ibunya saja serta dapat memiliki semua harta benda karna sifatnya kolektif.

Bila anak yang lahir tersebut laki-laki maka anak tersebut tidak memiliki hak waris, baik dari garis ibu ataupun garis ayah.

b) Masyarakat patrilineal

Bila anak yang lahir perempuan maka anak tersebut tidak dapat memiliki hak waris, baik dari garis ibu ataupun garis ayah.

Bila anak yang lahir laki-laki maka anak tersebut dapat mewaris dari garis ayah saja, walaupun ayah sudah meninggal.

c) Masyarakat Parental

Bila anak yang lahir perempuan atau anak lakilaki maka anak tersebut dapat mewaris dari garis ibu saja, karna di dalam masyarakat parental sistem kewarisannya adalah individual.

Jadi, dapat disimpulkan pada dasarnya anak hasil inseminasi buatan dari ayah yang telah meninggal baru lahir, maka anak tersebut dapat mewaris. Karna anak merupakan ahli waris yang pertama dan utama, baik laki-laki ataupun perempuan karna sifatnya yang turun menurun dari generasi ke generasi.

\section{Simpulan}

Kedudukan hukum anak hasil inseminasi buatan dari ayah yang telah meninggal menurut Kitab Undang-Undang Hukum Perdata adalah anak sah sesuai dengan Pasal 250 KUHPerdata, sedangkan menurut Hukum Islam kedudukan hukum anak hasil inseminasi buatan dari ayah yang telah meninggal merupakan anak sah hal ini sesuai dengan kaidah hukum Fiqih Islam yaitu "Hajat" dan dilakukan sebelum selesai waktu masa "iddah istri" serta menurut hukum adat bahwa anak tersebut merupakan anak sah hal ini dipersamakan dengan mengangkat anak dalam masyarakat adat.

Hak waris anak hasil inseminasi buatan dari ayah yang telah meninggal mempunyai hak mewaris. Menurut Perspektif Kitab Undang-undang Hukum Perdata bahwa anak hasil inseminasi buatan dari ayah yang telah meninggal mempunyai hak mewaris dari ibunya saja karna hal ini sesuai dengan Pasal 836 KUHPerdata, sedangkan menurut Hukum Islam anak hasil inseminasi buatan dari ayah yang telah meninggal mempunyai hak mewaris dari pihak ibu saja karna hal ini sesuai dengan syarat pewarisan dalam Islam, serta menurut hukum adat bahwa anak hasil inseminasi buatan dari ayah yang telah meninggal dapat mewaris dari pihak ayah yang telah meninggal karna anak merupakan ahli waris yang pertama dan utama, baik laki-laki ataupun perempuan karna sifatnya yang turun menurun dari generasi ke generasi.

\section{Daftar pustaka}

Abdurahman, H dan Soejono. 2003. Metode Penelitian Hukum. Rineka Cipta. Jakarta.

Afandi, Ali. 1986. Hukum Waris, Hukum Keluarga, Hukum Pembuktian Menurut Kitab Undang-Undang Hukum Perdata. Bina Aksara. Jakarta. 


\section{Jurnal Cakrawala Hukum, Volume 11 No. 3 Desember 2020}

ISSN PRINT 2356-4962 ISSN ONLINE 2598-6538

Gandasubrata, Purwoto S. 1989. Perkembangan Tekhnologi Reproduksi Baru dan Impikasi Hukumnya. ISWI. Jakarta.

Kitab Undang-Undang Hukum Perdata.

Meta, K., 2014. Kedudukan waris anak angkat menurut hukum waris adat Bali. Jurnal Cakrawala Hukum, 19(1), pp.39-48.

Rahmita, N.M. and Budiono, R., 2017. Analisis kompilasi hukum islam tentang tolok ukur hibah yang diperhitungkan sebagai warisan. Jurnal Cakrawala Hukum, 8(1), pp.75-85.
Sabardi, L., 2014. Perlindungan Konstitusional Hak Masyarakat Hukum Adat Atas Tanah. Jurnal Cakrawala Hukum, 19(1), pp.49-58.

Siregar, Bismar. 1989. Bayi Tabung Ditinjau Dari aspek hukum Pancasila. UNISRI. Surakarta.

Subekti. 2003. Pokok-Pokok Hukum Perdata. Intermesa. Jakarta.

Wulansari, Dewi. 2014. Hukum Adat Indonesia Suatu Pengantar. Refika Aditama. Bandung. 